\title{
Health literacy levels of British adults: a cross-sectional survey using two domains of the Health Literacy Questionnaire (HLQ)
}

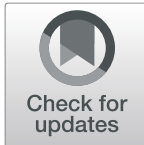

Rebecca M. Simpson ${ }^{*}$ D, Emma Knowles and Alicia O'Cathain

\begin{abstract}
Background: A person's health literacy determines whether they are able to make appropriate health decisions and are able to follow treatment instructions. This is important because low health literacy is associated with mortality and extra costs to the healthcare system. Our aim was to describe the health literacy levels of British adults using a nationally representative population survey, and show how health literacy levels vary by population characteristics.

Methods: A population based cross-sectional survey including questions from two domains from the Health Literacy Questionnaire $^{\text {TM. }}$. 1) Understanding health information well enough to know what to do, and 2) Ability to actively engage with health care providers. Both domains are made up of 5 Likert style questions with 5 levels ranging from 'cannot do or always difficult' (1) to 'always easy' (5). The survey was conducted by NatCen in Britain (2018) as part of the annual British Social Attitudes survey. We used weighted descriptive analyses and regression to explore the relationship between population characteristics and health literacy. Weighted analyses were used to ensure the sample was representative of the British population.
\end{abstract}

Results: A total of 2309 responded to the questionnaire. The mean score for 'understanding information' was 3.98 ( $95 \%$ Cl: 3.94 , 4.02) and for 'ability to engage' was 3.83 (95\% Cl: 3.80, 3.87), where 5 is the highest score. $19.4 \%$ had some level of difficulty reading and understanding written health information, and 23.2\% discussing health concerns with health care providers. The adjusted logistic regression for 'understanding information' showed that those with lower health literacy were more likely to be in the most socially deprived quintile (OR 2.500 95\% Cl: 1.180, 5.296), have a limiting health condition or disability (OR $4.32695 \% \mathrm{Cl}: 2.494,7.704)$, and have no educational qualifications (OR 7.588 $95 \%$ Cl: $3.305,17.422)$. This was similar for the 'ability to engage' domain.

Conclusions: This study described the distribution of health literacy levels for the British population in 2018. Interventions to improve health literacy will best be targeted at those with lower levels of education, those living in the most deprived areas, and those with a limiting health condition or disability.

Keywords: Health literacy, Health literacy questionnaire (HLQ), Health information, Population survey, Ability to engage, Understanding information, Communication

* Correspondence: r.simpson@sheffield.ac.uk

School of Health and Related Research, University of Sheffield, Sheffield, UK

(c) The Author(s). 2020 Open Access This article is licensed under a Creative Commons Attribution 4.0 International License, which permits use, sharing, adaptation, distribution and reproduction in any medium or format, as long as you give appropriate credit to the original author(s) and the source, provide a link to the Creative Commons licence, and indicate if changes were made. The images or other third party material in this article are included in the article's Creative Commons licence, unless indicated otherwise in a credit line to the material. If material is not included in the article's Creative Commons licence and your intended use is not permitted by statutory regulation or exceeds the permitted use, you will need to obtain permission directly from the copyright holder. To view a copy of this licence, visit http://creativecommons.org/licenses/by/4.0/ The Creative Commons Public Domain Dedication waiver (http://creativecommons.org/publicdomain/zero/1.0/) applies to the data made available in this article, unless otherwise stated in a credit line to the data. 


\section{Background}

A person's health literacy determines whether they are able to make appropriate health decisions and are able to follow treatment instructions $[1,2]$. Health literacy is based on a person's capability to understand, read, use and obtain health care information. Health literacy is important because low health literacy is associated with mortality [3], extra costs to the health care system [4] and lower levels of medication adherence [5].

Different instruments exist to measure health literacy. Some focus on objective measurement such as the Newest Vital Sign [6] and the Test of Functional Health Literacy in Adults [7] whereas others focus on a person's subjective assessment [812]. The Health Literacy Questionnaire ${ }^{\mathrm{TM}}$ (HLQ) is a measure based on a person's subjective assessment. It was developed and validated in Australia [8] and has been used to measure health literacy in different countries $[13,14]$. It consists of nine domains of health literacy: feeling understood and supported by healthcare providers, having sufficient information to manage health, actively managing health, social support for health, appraisal of health information, ability to actively engage with healthcare providers, navigating the healthcare system, ability to find good health information, and understanding health information enough to know what to do [8].

As part of a wider study focusing on decision-making when seeking emergency and urgent care, we measured health literacy within a population survey. We selected the $\mathrm{HLQ}^{\mathrm{TM}}$ as the most appropriate instrument to use because it is well-validated and easy to complete within a survey. We selected two of the nine domains that focus on understanding health information ('understanding information') and ability to actively engage with health professionals ('ability to engage'), because these are important for decision-making around seeking healthcare. A high score in the 'understanding information' domain indicates that a person feels capable of understanding written and numerical information about their health, including being able to complete forms relating to their treatment [8]. A high score in the 'ability to engage' domain indicates that the person feels able to be proactive when it comes to their health and feel in control in their relationships with health care professionals [8].

A number of studies have measured health literacy, using various tools, within different countries, investigating the level of health literacy and the characteristics affecting health literacy [15-17]. A study in Denmark in 2013 [15] found the largest differences in health literacy scores occurred by income and educational attainment, with those in lower income and education groups having lower health literacy. The Danish study also found that men had lower scores than women for the 'understanding information' domain of the HLQ ${ }^{\mathrm{TM}}$. A study in Australia in 2013-2014 found that the lowest health literacy scores occurred in those with lower education, those born overseas, and those who were not English speaking at home [16]. Differences were also seen for age, gender, chronic conditions and living arrangements [16]. A study in a single city in the UK in 2013 found that those in older age groups and those with lower education were more likely to have limited health literacy [17]. Deprivation was also found to impact on health literacy, with those in the most socially deprived groups more likely to have lower health literacy scores [17].

The aim of our study was to describe the health literacy levels of British adults using a nationally representative population survey and show how health literacy levels vary by population characteristics.

\section{Methods \\ Study population and data collection}

A population based cross-sectional survey was conducted in Britain. The survey was undertaken by NatCen Social Research who conduct an annual survey researching British social attitudes [18]. The survey is designed to be a representative sample of adults (over 18 years old) in Britain. They do this by using a three stage design. They start by selecting 395 postcode sectors with a probability that is proportional to the number of addresses in that sector. They then select 26 addresses within each sector; this produces 10 , 270 addresses. Finally, the interviewers call at each address and randomly select one adult over 18 to interview. The survey consisted of face to face administration of the questionnaire by an interviewer for most of the questions and a selfcomplete questionnaire for a small proportion of the questions. The questionnaire consisted of around 300 items administered to 4000 people. We bought a 60 -item module for our wider study, based on a representative sample of 3000 people. A license was obtained to use two health literacy domains ('understanding information' and 'ability to engage') from the $\mathrm{HLQ}^{\mathrm{Tm}}$, consisting of 10 items. These were asked within the self-completed questionnaire.

The survey was undertaken in the summer of 2018. The response rate to the whole British Social Attitudes Survey was $42 \%$. Of those who completed the face to face interview, the response rate for the self-competed questionnaire for our module was 79\% (2309) [18]. See Table 6 in the appendix for the characteristic breakdown between the interview administered and self-completed samples.

\section{Population characteristics}

A number of characteristics were collected as part of the survey: age, sex, living in household with children under 5, geographical region, educational attainment, living alone, ethnicity, income, whether they had visited a GP in the past 12 months and whether they were living with limiting long term conditions. NatCen provided deprivation scores using the Index of Multiple Deprivation (IMD) quintiles, and urban rural status with the dataset based on postcode of the respondent.

\section{Statistical analysis}

All analyses were completed using SPSS version 25. NatCen Social Research produced weights to address sample bias 
due to both selection probabilities and non-response, and to ensure the sample matched the population profile in terms of age, sex and geographical region. Separate weights were produced for interviewer-administered questions and selfcompleted questions due to differential response rates. The 'complex samples function' in SPSS was used for weighting the analysis, based on the self-completed weights.

The scores for each of the two health literacy domains were calculated from the 10 health literacy questions using the instrument's scoring rules. Each question had 5 responses: 1 = Cannot do or always difficult, $2=$ Usually difficult, 3 = Sometimes difficult, $4=$ Usually easy and $5=$ Always easy. For both the 'understanding information' and 'ability to engage' domains, the score range is $1-5$ and the overall score for each domain is an average score across all the questions from that domain. Missing data was imputed using the Expectation Maximisation algorithm. As both the scales were made up of 5 questions, missing data was only imputed if there were no more than two questions missing within a domain. If there were more the two questions missing, then a score was not calculated for that individual in that domain.

Analysis included frequencies and descriptive statistics of the individual health literacy items and the two domains scores, both overall and within the population characteristics described earlier. Generalised linear models within the SPSS complex sample function were used to compare means of both domains by each population characteristic (i.e. t-test and ANOVA).

To measure the relationship between the population characteristics and the two domains, linear regression was used. Univariable (unadjusted) linear regression was used for each characteristic variable and multivariable (adjusted) linear regression was used with all the characteristic variables to model both domains. All population characteristics were chosen a priori based on previous relevant literature $[15,16]$.

A binary variable was created to determine whether a person was in a 'lower health literacy' group for each domain because this offers more meaningful results. There is no recommended cut-off point to indicate low health literacy. We chose a cut off of $\leq 3$ for a domain because scores of 1 to 3 on each item indicate a level of difficulty ('cannot do or always difficult', 'usually difficult' or 'sometimes difficult'). Similarly to the linear regression analysis, univariable (unadjusted) logistic regression was used for each characteristic variable and multivariable (adjusted) logistic regression was used with all the characteristic variables to model both domains. The Odds Ratios (OR) presented show the odds of being in the 'lower health literacy' group compared to being in the 'higher health literacy' group.

\section{Ethics approval}

The NatCen Research Ethics Committee (REC) approved the British Social Attitudes survey (reference number P12598).

\section{Results}

\section{Description of sample}

The unweighted and weighted sample is presented in Table 1 . The mean age of respondents was 54, ranging between 18 and 99. For ethnicity, 91\% of the respondents were white and weighting changed this to $85 \%$, increasing the weight of Black Asian Minority Ethnic (BAME) people in the analysis.

\section{Description of health literacy levels}

The weighted distribution of responses to each item is presented in Table 2. Most of the population responded 'always easy' or 'usually easy' to all 10 items but around one in five had some level of difficulty. For example, 19.4\% had some level of difficulty reading and understanding written health information (item $3 \mathrm{U}$ ), and $23.2 \%$ discussing health concerns with health care providers (item $2 \mathrm{~A}$ ).

The mean score for the 'understanding information' domain was 3.98 (95\% CI: 3.94, 4.02). The mean score for the 'ability to engage' domain was 3.83 (95\% CI: 3.80, 3.87). Both domains had a modal score of 4 , with scores ranging from 1 to 5 .

\section{Health literacy by population characteristics}

Table 3 presents the itemised proportions of those who selected some level of difficulty ('cannot do or always difficult', 'usually difficult' or 'sometimes difficult') for each domain and the weighted mean score for each domain by the various subgroups.

The following subgroups had generally higher proportions of individuals selecting some level of difficulty over the five questions for both 'understanding information' and 'ability to engage': most socially deprived quintile, with a limiting health condition or disability, people who live alone, lower household incomes and BAME. This is reflected in the mean scores, with the following subgroups having lower scores for both domains: men, most socially deprived quintile, with a limiting health condition or disability, lower levels of education, people who live alone, lower household incomes and BAME. For example, for one of the items in the 'understanding information' domain, 34\% of people living in the most socially deprived communities expressed some level of difficulty compared with $13 \%$ in the most affluent quintile.

\section{Regression analysis}

Table 4 presents the unadjusted and adjusted linear regression results for both the 'understanding information' and 'ability to engage' domains for each of the subgroups of interest, based on the mean of each domain.

The adjusted regression results for the 'understanding information' domain suggest that those with lower health literacy scored were males $(-0.130$ 95\% CI: $-0.197,-0.063)$ compared to females, those in the most socially deprived quintile $(-0.16895 \% \mathrm{CI}:-0.282,-0.053)$ compared to those in the highest deprivation quintile, those who have a 
Table 1 Description of sample $N=2309$

\begin{tabular}{|c|c|c|c|c|c|}
\hline & & Unweighted Count & Unweighted \% & Weighted \% & Unweighted missing \\
\hline \multirow[t]{2}{*}{ Sex } & Male & 974 & $42.2 \%$ & $47.8 \%$ & 0 \\
\hline & Female & 1335 & $57.8 \%$ & $52.2 \%$ & \\
\hline \multirow[t]{7}{*}{ Age } & $18-24$ & 133 & $5.8 \%$ & $10.7 \%$ & 5 \\
\hline & $25-34$ & 291 & $12.6 \%$ & $17.1 \%$ & \\
\hline & $35-44$ & 348 & $15.1 \%$ & $15.9 \%$ & \\
\hline & $45-54$ & 382 & $16.6 \%$ & $17.8 \%$ & \\
\hline & $55-64$ & 414 & $18.0 \%$ & $15.4 \%$ & \\
\hline & $65-74$ & 424 & $18.4 \%$ & $13.8 \%$ & \\
\hline & $75+$ & 312 & $13.5 \%$ & $9.3 \%$ & \\
\hline \multirow{2}{*}{$\begin{array}{l}\text { Number of children under } 5 \text { years } \\
\text { old living in household }\end{array}$} & 0 & 2075 & $90.3 \%$ & $87.9 \%$ & 11 \\
\hline & $1+$ & 223 & $9.7 \%$ & $12.1 \%$ & \\
\hline \multirow[t]{6}{*}{ Region } & North & 377 & $16.3 \%$ & $16.0 \%$ & 0 \\
\hline & Midlands & 617 & $26.7 \%$ & $24.2 \%$ & \\
\hline & South & 785 & $34.0 \%$ & $32.1 \%$ & \\
\hline & London & 219 & $9.5 \%$ & $13.8 \%$ & \\
\hline & Wales & 107 & $4.6 \%$ & $5.4 \%$ & \\
\hline & Scotland & 204 & $8.8 \%$ & $8.5 \%$ & \\
\hline \multirow[t]{5}{*}{ IMD Quintile } & 1 (Most deprived) & 418 & $18.1 \%$ & $21.5 \%$ & 0 \\
\hline & 2 & 405 & $17.5 \%$ & $19.2 \%$ & \\
\hline & 3 & 448 & $19.4 \%$ & $18.2 \%$ & \\
\hline & 4 & 528 & $22.9 \%$ & $20.5 \%$ & \\
\hline & 5 (Least deprived) & 510 & $22.1 \%$ & $20.6 \%$ & \\
\hline \multirow[t]{2}{*}{ Urban Rural } & Urban & 1750 & $75.8 \%$ & $78.6 \%$ & 0 \\
\hline & Rural & 559 & $24.2 \%$ & $21.4 \%$ & \\
\hline \multirow[t]{3}{*}{ Long Term Condition } & $\begin{array}{l}\text { No long term health condition } \\
\text { or disability }\end{array}$ & 1376 & $59.8 \%$ & $63.1 \%$ & 7 \\
\hline & $\begin{array}{l}\text { Non-limiting health condition } \\
\text { or disability }\end{array}$ & 499 & $21.7 \%$ & $20.2 \%$ & \\
\hline & $\begin{array}{l}\text { Limiting health condition } \\
\text { or disability }\end{array}$ & 427 & $18.5 \%$ & $16.7 \%$ & \\
\hline \multirow[t]{4}{*}{ Education } & Degree or equivalent & 640 & $28.2 \%$ & $28.0 \%$ & 36 \\
\hline & A level or equivalent & 616 & $27.1 \%$ & $26.9 \%$ & \\
\hline & GCSE or equivalent & 590 & $26.0 \%$ & $26.9 \%$ & \\
\hline & No Qualification & 427 & $18.8 \%$ & $18.2 \%$ & \\
\hline \multirow[t]{2}{*}{ Live Alone } & Alone & 702 & $30.4 \%$ & $17.3 \%$ & 0 \\
\hline & Not alone & 1607 & $69.6 \%$ & $82.7 \%$ & \\
\hline \multirow[t]{2}{*}{ Visited GP in the last 12 months } & In last 12 months & 1924 & $83.3 \%$ & $83.1 \%$ & 0 \\
\hline & More than 12 Months/never & 385 & $16.7 \%$ & $16.9 \%$ & \\
\hline \multirow[t]{5}{*}{ Household income } & Less than $£ 1200$ p.m & 462 & $21.9 \%$ & $18.6 \%$ & 202 \\
\hline & $£ 1200-2200$ p.m & 470 & $22.3 \%$ & $21.3 \%$ & \\
\hline & $£ 2201-3700$ p.m & 433 & $20.6 \%$ & $21.3 \%$ & \\
\hline & $£ 3701$ or more p.m & 456 & $21.6 \%$ & $23.5 \%$ & \\
\hline & Refused information & 286 & $13.6 \%$ & $15.3 \%$ & \\
\hline \multirow[t]{2}{*}{ Ethnicity } & White & 2098 & $90.9 \%$ & $85.2 \%$ & 0 \\
\hline & Black Asian and Minority Ethnic (BAME) & 211 & $9.1 \%$ & $14.8 \%$ & \\
\hline
\end{tabular}

p.m per month

IMD Index of Multiple Deprivation, GCSE General Certificate of Secondary Education 
Table 2 Weighted response to each question in the 'understanding information' and 'ability to engage' domains

\begin{tabular}{|c|c|c|c|c|c|c|}
\hline Items $^{a}$ & $\begin{array}{l}\text { Cannot do or } \\
\text { always difficult }\end{array}$ & $\begin{array}{l}\text { Usually } \\
\text { difficult }\end{array}$ & $\begin{array}{l}\text { Sometimes } \\
\text { difficult }\end{array}$ & $\begin{array}{l}\text { Usually } \\
\text { easy }\end{array}$ & $\begin{array}{l}\text { Always } \\
\text { easy }\end{array}$ & $\begin{array}{l}\text { Low Health } \\
\text { Literacy }^{\mathbf{b}}\end{array}$ \\
\hline \multicolumn{7}{|l|}{ UNDERSTANDING INFORMATION } \\
\hline Confidently fill medical forms in the correct way (1U) & $1.5 \%$ & $4.7 \%$ & $15.4 \%$ & $58.0 \%$ & $20.4 \%$ & $21.6 \%$ \\
\hline Accurately follow instructions from ... (2U) & $0.9 \%$ & $1.8 \%$ & $12.5 \%$ & $62.8 \%$ & $21.9 \%$ & $15.2 \%$ \\
\hline Read and understand written health information (3U) & $1.4 \%$ & $3.4 \%$ & $14.6 \%$ & $56.2 \%$ & $24.4 \%$ & $19.4 \%$ \\
\hline $\begin{array}{l}\text { Read and understand all the information on } \\
\text { medication labels (4U) }\end{array}$ & $1.4 \%$ & $3.3 \%$ & $14.9 \%$ & $57.2 \%$ & $23.2 \%$ & $19.6 \%$ \\
\hline $\begin{array}{l}\text { Understand what healthcare providers are asking you } \\
\text { to do }(5 \mathrm{U})\end{array}$ & $0.9 \%$ & $2.3 \%$ & $13.3 \%$ & $63.4 \%$ & $20.1 \%$ & $16.5 \%$ \\
\hline \multicolumn{7}{|l|}{ ABILITY TO ENGAGE } \\
\hline $\begin{array}{l}\text { Make sure that healthcare providers understand your } \\
\text { problems properly (1A) }\end{array}$ & $1.6 \%$ & $5.2 \%$ & $28.3 \%$ & $54.9 \%$ & $10.2 \%$ & $35.1 \%$ \\
\hline $\begin{array}{l}\text { Feel able to discuss your health concerns with a } \\
\text { healthcare provider ( } 2 A)\end{array}$ & $1.1 \%$ & $4.1 \%$ & $18.0 \%$ & $60.7 \%$ & $16.1 \%$ & $23.2 \%$ \\
\hline $\begin{array}{l}\text { Have good discussions about your health with } \\
\text { doctors }(3 A)\end{array}$ & $1.9 \%$ & $5.1 \%$ & $18.7 \%$ & $55.9 \%$ & $18.4 \%$ & $25.7 \%$ \\
\hline $\begin{array}{l}\text { Discuss things with healthcare providers until you } \\
\text { understand all you need to (4A) }\end{array}$ & $1.2 \%$ & $3.6 \%$ & $20.1 \%$ & $56.2 \%$ & $18.9 \%$ & $24.9 \%$ \\
\hline $\begin{array}{l}\text { Ask healthcare providers questions to get the health } \\
\text { information ... (5A) }\end{array}$ & $0.9 \%$ & $4.2 \%$ & $17.6 \%$ & $58.4 \%$ & $19.0 \%$ & $22.7 \%$ \\
\hline
\end{tabular}

${ }^{{ }^{a}}$ Some of the $H L Q^{T M}$ items have been truncated. $\mathrm{HLQ}^{\mathrm{TM}}$ is protected by copyright and cannot be used without permission of the authors. Full copy of the items is available at hlq@deakin.edu.au or globalhealthandequity@swin.edu.au

bow health literacy defined as 'Cannot do ...', 'Usually difficult' and 'Sometimes difficult'

limiting health condition or disability $(-0.17295 \% \mathrm{CI}$ : $-0.285,-0.059)$ compared to those who do not have one, and all education levels compared to those with a degree, ranging from -0.157 to -0.444 . Finally, those who do not live alone have a higher health literacy score $(0.12595 \% \mathrm{CI}$ : $0.043,0.207)$ compared to those who do live alone.

The adjusted regression for the 'ability to engage' domain suggests those with a lower health literacy score were the most deprived ( $-0.15595 \% \mathrm{CI}:-0.272,-0.037)$ compared to the least deprived group, those who have a limiting health condition or disability $(-0.254$ 95\% CI: $-0.375,-0.132)$ compared to those who do not have one, and all education levels when compared to those with a degree, ranging from -0.136 to -0.281 . The results suggest that those not living alone have a higher health literacy score $(0.112$ 95\% CI: $0.030,0.194$ ) compared to those who do live alone.

Table 5 shows the results of a comparison of the characteristics of the proportion of the population with lower health literacy levels (likely to have expressed some level of difficulty). It displays the unadjusted and adjusted logistic regression results for both the 'understanding information' and 'ability to engage' domains for each of the subgroups of interest.

The adjusted logistic regression results for the 'understanding information' domain suggest that those who were more likely to be in the 'lower health literacy' group were those most socially deprived (OR 2.500 95\% CI: 1.180, 5.296) compared to the least deprived group, both those with a non-limiting health condition or disability (OR 1.840
95\% CI: $1.000,3.385)$ and a limiting health condition or disability compared to those who do not have one (OR 4.326 95\% CI: 2.494, 7.704), those with lower levels of education (OR ranging from 2.537 to 7.588 ) when compared to those with a degree, and those from BAME communities (OR 3.472 95\% CI: $1.721,6.993)$ when compared to white population. Those not living alone were less likely to be in the 'lower health literacy' group (OR 0.602 95\% CI: 0.363, 0.986) when compared to those who do live alone.

Similarly, the adjusted logistic regression results for the 'ability to engage' domain suggest that those who were more likely to be in the 'lower health literacy' group were those most socially deprived (OR 2.020 95\% CI: 1.177, 3.467) compared to the least deprived group, both those with a non-limiting health condition or disability (OR $1.88295 \%$ CI: 1.284, 2.758) and a limiting health condition or disability compared to those who do not have one (OR 3.102 95\% CI: 1.939, 4.963) and those with lower levels of education (OR ranging from 1.716 to 2.973) when compared to those with a degree.

\section{Discussion}

The health literacy levels of the British population are described here. The overall mean score for the 'understanding information' domain was 3.98 (95\% CI: 3.94, 4.02) and the overall mean score for the 'ability to engage' domain was 3.83 (95\% CI: 3.80, 3.87). 19.4\% had some level of difficulty reading and understanding written health information, and 23.2\% discussing health concerns with health care 


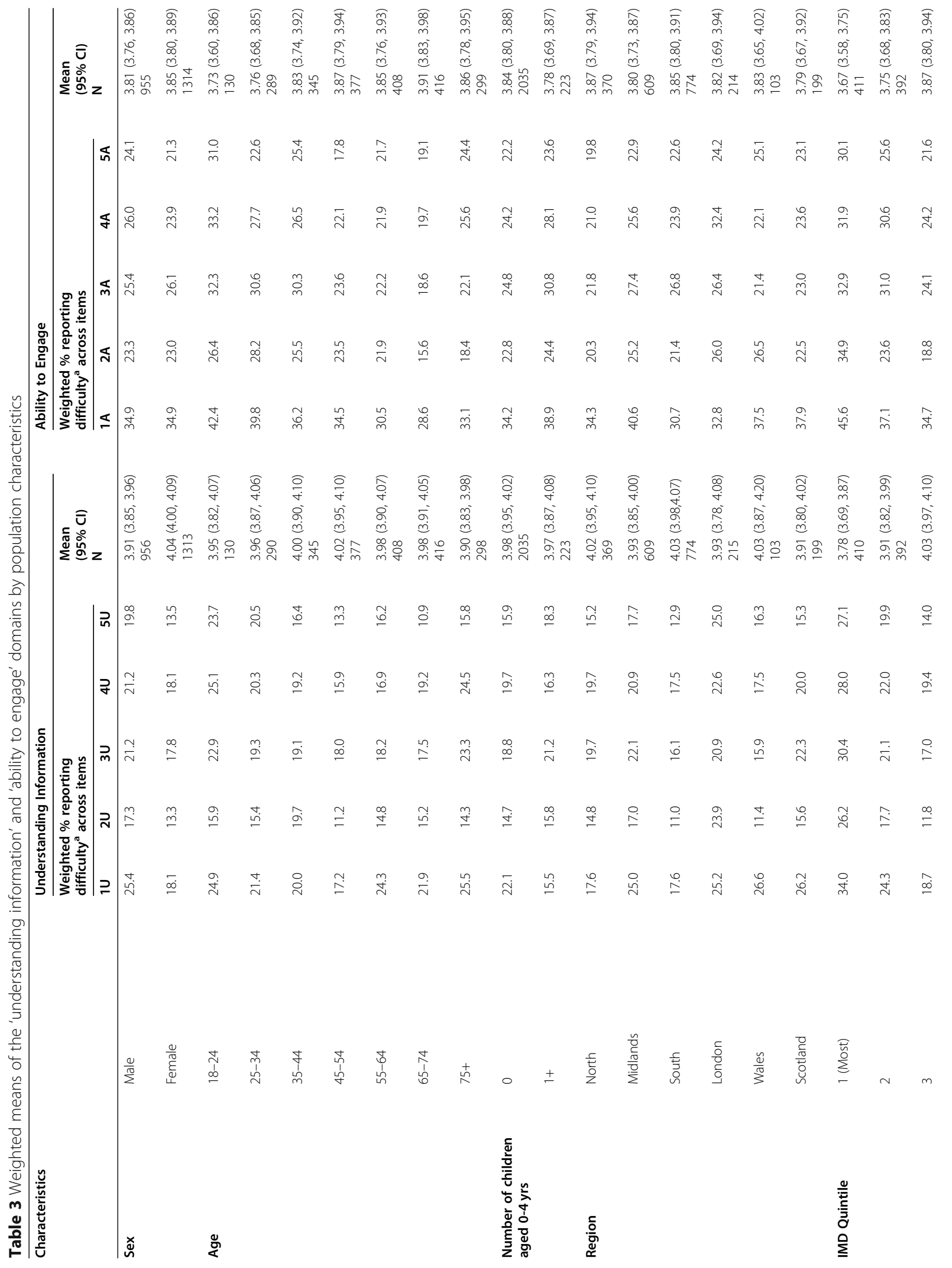




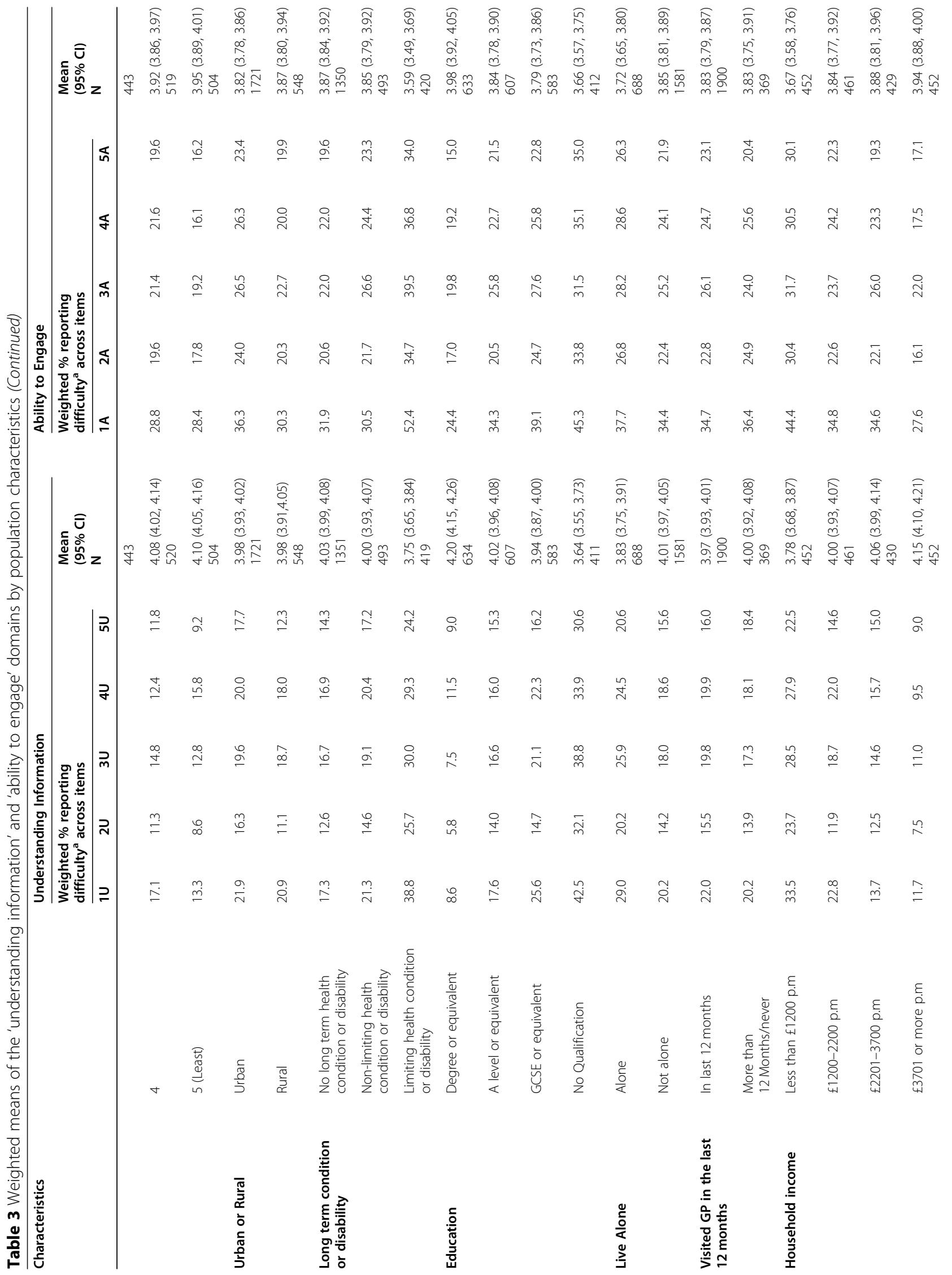




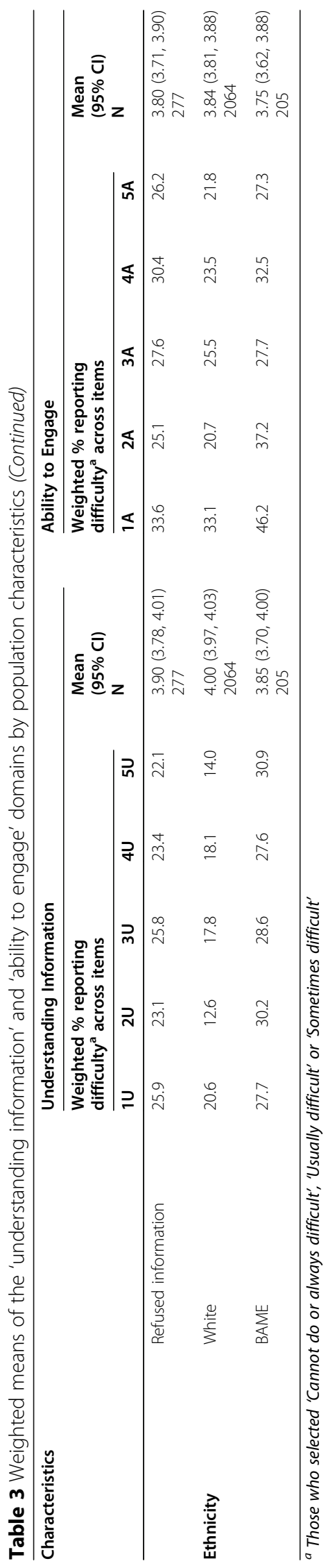




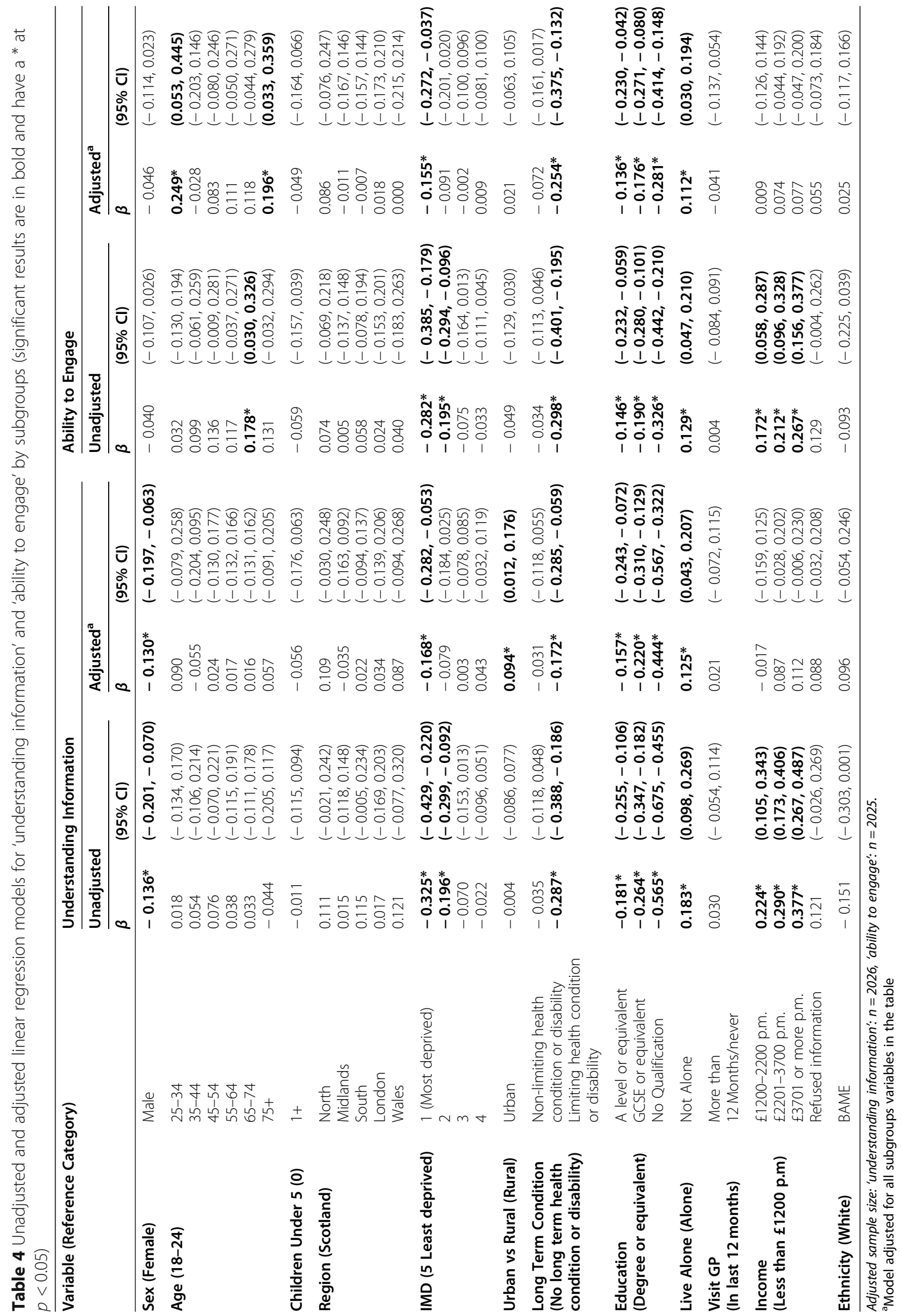


Table 5 Unadjusted and adjusted logistic regression models for 'understanding information' and 'ability to engage' by subgroups (significant results are in bold and have $a^{*}$ at $p<0.05$ )

\begin{tabular}{|c|c|c|c|c|c|c|c|c|c|}
\hline \multirow[t]{3}{*}{ Variable (Reference Category) } & & \multicolumn{4}{|c|}{ Understanding Information } & \multicolumn{4}{|c|}{ Ability to Engage } \\
\hline & & \multicolumn{2}{|c|}{ Unadjusted } & \multicolumn{2}{|c|}{ Adjusted $^{\mathrm{a}}$} & \multicolumn{2}{|c|}{ Unadjusted } & \multicolumn{2}{|c|}{ Adjusted $^{a}$} \\
\hline & & $\beta$ & $(95 \% \mathrm{Cl})$ & $\beta$ & $(95 \% \mathrm{Cl})$ & $\beta$ & $\begin{array}{l}(95 \% \\
\mathrm{Cl})\end{array}$ & $\beta$ & $\begin{array}{l}(95 \% \\
\mathrm{Cl})\end{array}$ \\
\hline Sex (Female) & Male & 1.305 & $\begin{array}{l}(0.900, \\
1.890)\end{array}$ & 1.217 & $\begin{array}{l}(0.792, \\
1.869)\end{array}$ & 1.105 & $\begin{array}{l}(0.820 \\
1.489)\end{array}$ & 1.131 & $\begin{array}{l}(0.807 \\
1.585)\end{array}$ \\
\hline Age (18-24) & $\begin{array}{l}25-34 \\
35-44 \\
45-54 \\
55-64 \\
65-74 \\
75+\end{array}$ & $\begin{array}{l}1.510 \\
1.277 \\
0.856 \\
0.899 \\
0.770 \\
1.288\end{array}$ & $\begin{array}{l}(0.670, \\
3.401) \\
(0.493, \\
3.309) \\
(0.353, \\
2.075) \\
(0.365, \\
2.213) \\
(0.302, \\
1.967) \\
(0.514 \\
3.225)\end{array}$ & $\begin{array}{l}1.727 \\
1.086 \\
0.910 \\
0.749 \\
0.511 \\
0.549\end{array}$ & $\begin{array}{l}(0.631, \\
4.730) \\
(0.363, \\
3.243) \\
(0.301, \\
2.752) \\
(0.237, \\
2.365) \\
(0.153, \\
1.707) \\
(0.157, \\
1.919)\end{array}$ & $\begin{array}{l}0.866 \\
0.806 \\
0.587 \\
0.775 \\
\mathbf{0 . 4 6 1 *} \\
0.588\end{array}$ & $\begin{array}{l}(0.432, \\
1.739) \\
(0.407, \\
1.598) \\
(0.312, \\
1.104) \\
(0.417, \\
1.441) \\
(\mathbf{0 . 2 2 6}, \\
\mathbf{0 . 9 4 1 )} \\
(0.299, \\
1.153)\end{array}$ & $\begin{array}{l}0.975 \\
0.688 \\
0.507 \\
0.579 \\
\mathbf{0 . 3 2}^{*} \\
\mathbf{0 . 2 5 1}^{*}\end{array}$ & $\begin{array}{l}(0.434, \\
2.192) \\
(0.328, \\
1.444) \\
(0.241, \\
1.067) \\
(0.271, \\
1.236) \\
(\mathbf{0 . 1 3 8 ,} \\
\mathbf{0 . 7 5 6 )} \\
\mathbf{( 0 . 0 9 5 ,} \\
\mathbf{0 . 6 6 9 )}\end{array}$ \\
\hline Children Under 5 (0) & $1+$ & 1.265 & $\begin{array}{l}(0.702 \\
2.277)\end{array}$ & 1.078 & $\begin{array}{l}(0.478, \\
2.436)\end{array}$ & 0.892 & $\begin{array}{l}(0.542, \\
1.468)\end{array}$ & 0.700 & $\begin{array}{l}(0.371 \\
1.322)\end{array}$ \\
\hline Region (Scotland) & $\begin{array}{l}\text { North } \\
\text { Midlands } \\
\text { South } \\
\text { London } \\
\text { Wales }\end{array}$ & $\begin{array}{l}0.961 \\
1.340 \\
0.659 \\
1.928 \\
0.590\end{array}$ & $\begin{array}{l}(0.458, \\
2.017) \\
(0.666, \\
2.694) \\
(0.329, \\
1.320) \\
(0.835, \\
4.450) \\
(0.149, \\
2.346)\end{array}$ & $\begin{array}{l}0.893 \\
1.702 \\
0.898 \\
1.225 \\
0.761\end{array}$ & $\begin{array}{l}(0.388, \\
2.058) \\
(0.796, \\
3.640) \\
(0.429, \\
1.881) \\
(0.490, \\
3.058) \\
(0.253, \\
2.291)\end{array}$ & $\begin{array}{l}0.771 \\
0.949 \\
0.620 \\
1.054 \\
0.977\end{array}$ & $\begin{array}{l}(0.423, \\
1.406) \\
(0.558, \\
1.617) \\
(0.367, \\
1.047) \\
(0.561, \\
1.979) \\
(0.428, \\
2.228)\end{array}$ & $\begin{array}{l}0.699 \\
0.925 \\
0.725 \\
0.950 \\
1.263\end{array}$ & $\begin{array}{l}(0.386, \\
1.267) \\
(0.522, \\
1.641) \\
(0.423, \\
1.244) \\
(0.464, \\
1.945) \\
(0.576, \\
2.769)\end{array}$ \\
\hline IMD (5 Least deprived) & $\begin{array}{l}1 \text { (Most deprived) } \\
2 \\
3 \\
4\end{array}$ & $\begin{array}{l}6.024^{*} \\
3.655^{*} \\
2.245^{*} \\
1.289\end{array}$ & $\begin{array}{l}(3.229, \\
11.239) \\
(1.884, \\
7.090) \\
(1.164, \\
4.328) \\
(0.622, \\
2.673)\end{array}$ & $\begin{array}{l}\mathbf{2 . 5 0 0 *} \\
1.559 \\
1.185 \\
0.715\end{array}$ & $\begin{array}{l}\mathbf{( 1 . 1 8 0 ,} \\
\mathbf{5 . 2 9 6 )} \\
(0.750 \\
3.242) \\
(0.567 \\
2.477) \\
(0.328 \\
1.559)\end{array}$ & $\begin{array}{l}3.136^{*} \\
\mathbf{2 . 0 7 9 *} \\
1.417 \\
1.379\end{array}$ & $\begin{array}{l}(2.009, \\
4.895) \\
(1.296, \\
3.335) \\
(0.875, \\
2.296) \\
(0.876, \\
2.171)\end{array}$ & $\begin{array}{l}\mathbf{2 . 0 2 0 *} \\
1.411 \\
1.041 \\
1.301\end{array}$ & $\begin{array}{l}\mathbf{( 1 . 1 7 7 ,} \\
\mathbf{3 . 4 6 7 )} \\
(0.824, \\
2.419) \\
(0.592, \\
1.829) \\
(0.786, \\
2.153)\end{array}$ \\
\hline Urban vs Rural (Rural) & Urban & 1.389 & $\begin{array}{l}(0.890 \\
2.168)\end{array}$ & 0.625 & $\begin{array}{l}(0.353 \\
1.108)\end{array}$ & 1.249 & $\begin{array}{l}(0.890, \\
1.751)\end{array}$ & 0.875 & $\begin{array}{l}(0.606 \\
1.262)\end{array}$ \\
\hline $\begin{array}{l}\text { Long Term Condition (No long term } \\
\text { health condition or disability) }\end{array}$ & $\begin{array}{l}\text { Non-limiting health } \\
\text { condition or disability } \\
\text { Limiting health condition } \\
\text { or disability }\end{array}$ & $\begin{array}{l}1.250 \\
3.587^{*}\end{array}$ & $\begin{array}{l}(0.705 \\
2.213) \\
(\mathbf{2 . 2 1 8} \\
\mathbf{5 . 8 0 0 )}\end{array}$ & $\begin{array}{l}1.840^{*} \\
4.326^{*}\end{array}$ & $\begin{array}{l}(1.000, \\
3.385) \\
(2.494, \\
7.504)\end{array}$ & $\begin{array}{l}1.522^{*} \\
3.031^{*}\end{array}$ & $\begin{array}{l}(1.052, \\
2.200) \\
(2.077, \\
4.424)\end{array}$ & $\begin{array}{l}1.882^{*} \\
3.102^{*}\end{array}$ & $\begin{array}{l}(1.284, \\
2.758) \\
(1.939, \\
4.963)\end{array}$ \\
\hline Education (Degree or equivalent) & $\begin{array}{l}\text { A level or equivalent } \\
\text { GCSE or equivalent } \\
\text { No Qualification }\end{array}$ & $\begin{array}{l}1.470 \\
\mathbf{2 . 5 3 4 ^ { * }} \\
\mathbf{8 . 6 6 2}^{*}\end{array}$ & $\begin{array}{l}(0.762 \\
2.835) \\
(1.427 \\
4.498) \\
(4.648, \\
16.142)\end{array}$ & $\begin{array}{l}1.624 \\
2.537^{*} \\
7.588^{*}\end{array}$ & $\begin{array}{l}(0.711, \\
3.710) \\
(1.178, \\
5.463) \\
(3.305 \\
17.422)\end{array}$ & $\begin{array}{l}1.287 \\
1.678^{*} \\
2.855^{*}\end{array}$ & $\begin{array}{l}(0.831, \\
1.995) \\
(1.125, \\
2.504) \\
(1.796, \\
4.536)\end{array}$ & $\begin{array}{l}1.36 \\
1.716^{*} \\
2.973^{*}\end{array}$ & $\begin{array}{l}(0.834, \\
2.217) \\
(1.063, \\
2.769) \\
(1.557, \\
\mathbf{5 . 6 7 4 )}\end{array}$ \\
\hline Live Alone (Alone) & Not Alone & $0.510^{*}$ & $\begin{array}{l}(0.351, \\
0.741)\end{array}$ & $0.602^{*}$ & $\begin{array}{l}(0.368, \\
0.986)\end{array}$ & $0.702^{*}$ & $\begin{array}{l}(0.519 \\
0.952)\end{array}$ & 0.756 & $\begin{array}{l}(0.525 \\
1.088)\end{array}$ \\
\hline Visit GP (In last 12 months) & $\begin{array}{l}\text { More than } 12 \text { Months/ } \\
\text { never }\end{array}$ & 0.988 & $\begin{array}{l}(0.574 \\
1.702)\end{array}$ & 1.077 & $\begin{array}{l}(0.561 \\
2.069)\end{array}$ & 0.986 & $\begin{array}{l}(0.653 \\
1.489)\end{array}$ & 1.129 & $\begin{array}{l}(0.716 \\
1.781)\end{array}$ \\
\hline Income (Less than $£ 1200$ p.m) & $\begin{array}{l}£ 1200-2200 \text { p.m. } \\
£ 2201-3700 \text { p.m. } \\
£ 3701 \text { or more p.m. } \\
\text { Refused information }\end{array}$ & $\begin{array}{l}0.467^{*} \\
0.283^{*} \\
0.151^{*} \\
0.604\end{array}$ & $\begin{array}{l}(0.277, \\
0.788) \\
(0.149, \\
0.539) \\
(0.075, \\
0.306) \\
(0.332 \\
1.100)\end{array}$ & $\begin{array}{l}0.974 \\
0.622 \\
0.789 \\
1.015\end{array}$ & $\begin{array}{l}(0.279, \\
1.388) \\
(0.324, \\
1.921) \\
(0.324, \\
1.921) \\
(0.544, \\
1.744)\end{array}$ & $\begin{array}{l}0.573 \\
0.549^{*} \\
0.428^{*} \\
0.605^{*}\end{array}$ & $\begin{array}{l}(0.370, \\
0.886) \\
(0.351, \\
0.859) \\
(0.273, \\
0.671) \\
(0.378, \\
0.968)\end{array}$ & $\begin{array}{l}0.812 \\
0.966 \\
1.027 \\
0.872\end{array}$ & $\begin{array}{l}(0.489, \\
1.348) \\
(0.559, \\
1.671) \\
(0.574, \\
1.836) \\
(0.509, \\
1.496)\end{array}$ \\
\hline
\end{tabular}


Table 5 Unadjusted and adjusted logistic regression models for 'understanding information' and 'ability to engage' by subgroups (significant results are in bold and have $a^{*}$ at $\left.p<0.05\right)$ (Continued)

\begin{tabular}{|c|c|c|c|c|c|c|c|c|c|}
\hline \multirow[t]{3}{*}{ Variable (Reference Category) } & & \multicolumn{4}{|c|}{ Understanding Information } & \multicolumn{4}{|c|}{ Ability to Engage } \\
\hline & & \multicolumn{2}{|c|}{ Unadjusted } & \multicolumn{2}{|c|}{ Adjusted $^{a}$} & \multicolumn{2}{|c|}{ Unadjusted } & \multicolumn{2}{|c|}{ Adjusted $^{\mathrm{a}}$} \\
\hline & & $\beta$ & $(95 \% \mathrm{Cl})$ & $\beta$ & $(95 \% \mathrm{Cl})$ & $\beta$ & $\begin{array}{l}(95 \% \\
\mathrm{Cl})\end{array}$ & $\beta$ & $\begin{array}{l}(95 \% \\
\mathrm{Cl})\end{array}$ \\
\hline Ethnicity (White) & BAME & $3.546^{*}$ & $\begin{array}{l}(2.179 \\
5.780)\end{array}$ & $3.472^{*}$ & $\begin{array}{l}(1.721, \\
6.993)\end{array}$ & $1.680^{*}$ & $\begin{array}{l}(1.120, \\
2.540)\end{array}$ & 1.399 & $\begin{array}{l}(0.775 \\
2.525)\end{array}$ \\
\hline
\end{tabular}

Odd ratios represent the odds of being in the 'lower literacy' group compared to the 'higher literacy group'. Lower literacy is a score $\leq 3$ on the final domain score Adjusted sample size: 'understanding information': $n=2026$, 'ability to engage': $n=2025$

${ }^{a}$ Model adjusted for all subgroups variables in the table

providers. The adjusted logistic regression for the 'understanding information' domain showed that those with lower health literacy were more likely to be in the most socially deprived quintile, have a limiting health condition or disability, have no educational qualifications and be from Black Asian and Minority Ethnic communities. This was similar for the 'ability to engage' domain with the exception of the finding about BAME.

The Australian Bureau of Statistics (ABS) conducted a national health survey in 2018 exploring health literacy levels using all domains of the HLQ ${ }^{\mathrm{ru}}$. For the 'ability to engage' domain, $11 \%$ of the population reported some degree of difficulty to engage, whereas the remaining percentage found it easy. Similarly, for the 'understanding information' domain, 7\% of the population reported difficultly when trying to understand information [19]. This study reported smaller percentages of lower health literacy than we found in our results. It is not easy to make comparisons between countries as there is no validated questionnaire for inter country comparison. When comparing results between different countries caution needs to be taken as the context and social attitudes are different which could affect how respondents score health literacy questions. Another similar study, conducted in Denmark in 2013, found that $12.8 \%$ had some level of difficulty reading and understanding written health information, and $14.5 \%$ had some level of difficulty discussing health concerns with health care providers [15]. Again, these percentages are smaller than our study results. It is important to note, that even though the same questionnaire was used in the Denmark study, they used a four point scale instead of five.

Our results about the characteristics of lower health literacy were similar to those found in other countries and using different measures of health literacy, including objective measures. A study conducted in a city in England found that those living in the most deprived areas were twice as likely to have low health literacy compared to those in the least deprived area [17]. A number of studies have shown that education impacts on health literacy, with lower education associated with lower health literacy levels [15-17]. Living alone has been found to be associated with lower health literacy in Denmark [15], but not in an Australian study [16]. The Australian study investigated the effect of having four or more chronic conditions on a person's health literacy; they found an association but this was not statistically significant for the 'ability to engage' and 'understanding information' domains [16]. Another study conducted in Denmark concluded that those with chronic conditions found it more difficult to understand health information and engage with healthcare providers [13]. All of these studies also used the Health Literacy Questionnaire ${ }^{\mathrm{m} m}$.

There were some differences between our study and others. In the Danish study, similarly to our study they found that males had lower health literacy for the 'understanding information' domain but in contrast they found that males had higher scores for the 'ability to engage' domain [15].

\section{Strengths and limitations}

This study had two main strengths. First, the design and analysis of the survey means the results are likely to be representative of the British population. Second, the $\mathrm{HLQ}^{\mathrm{m}}$ is a well validated questionnaire $[8,20,21]$. The study also had four potential limitations. First, as participation in the survey was voluntary, some of those asked may have declined due to having lower levels of English language and literacy. Alongside this, the health literacy questions were part of the self-complete questionnaire so for the same reasons, people with poorer literacy may have decided not to return the questionnaire. In the appendix we show a comparison between the interview administered sample and the self-complete sample, showing a small under representation of people from socially deprived communities completing the health literacy items Table 6 . This suggests that our results are likely to overestimate health literacy levels in Britain. Second, we opted to include only two of the nine health literacy domains in the HLQ ${ }^{\mathrm{mw}}$, so only addressed some aspects of health literacy. Third, some of the ORs are large due to small sample sizes in some categories. Fourth, the analysis was conducted using the complex samples function within SPSS to allow for the sample weighting. A limitation of this function is that non-parametric methods cannot be used and the data were slightly skewed. However, given the sample size and the robustness of parametric methods, we do not believe that this was a problem in practice.

\section{Implications}

Given the association between low health literacy and mortality, lower medication adherence and extra health 
care costs, variation in health literacy levels are of concern. This study has identified groups to target with interventions including socially deprived communities, those with low education, those with limiting health condition or disability, and those living alone. The survey reported here has also offered a national baseline for any national initiative to improve health literacy in the future.

\section{Conclusion}

This study has described the distribution of health literacy levels for 'understanding information' and 'ability to engage' with health professionals for the British population in 2018. Interventions to improve health literacy will best be targeted at those with lower levels of education, those living in the most deprived areas, those with a limiting health condition or disability and those who live alone.

\section{Appendix}

Table 6 Differences between interview administered and self-complete sample

\begin{tabular}{|c|c|c|c|c|c|c|c|}
\hline Characteristic & & $\begin{array}{l}\text { Interview administered } \\
\text { Sample Count } \\
N=2906\end{array}$ & $\%$ & Missing & $\begin{array}{l}\text { Self-complete } \\
\text { Sample Count } \\
N=2309\end{array}$ & $\%$ & Missing \\
\hline Sex & $\begin{array}{l}\text { Male } \\
\text { Female }\end{array}$ & $\begin{array}{l}1257 \\
1649\end{array}$ & $\begin{array}{l}43.3 \\
56.7\end{array}$ & 0 & $\begin{array}{l}974 \\
1335\end{array}$ & $\begin{array}{l}42.2 \\
57.8\end{array}$ & 0 \\
\hline Age & $\begin{array}{l}18-24 \\
25-34 \\
35-44 \\
45-54 \\
55-64 \\
65-74 \\
75+\end{array}$ & $\begin{array}{l}169 \\
384 \\
467 \\
469 \\
508 \\
499 \\
405\end{array}$ & $\begin{array}{l}5.8 \\
13.2 \\
16.1 \\
16.2 \\
17.5 \\
17.2 \\
14.0\end{array}$ & 5 & $\begin{array}{l}133 \\
291 \\
348 \\
382 \\
414 \\
424 \\
312\end{array}$ & $\begin{array}{l}5.8 \\
12.6 \\
15.1 \\
16.6 \\
18.0 \\
18.4 \\
13.5\end{array}$ & 5 \\
\hline $\begin{array}{l}\text { Number of children under } \\
5 \text { years old living in } \\
\text { household }\end{array}$ & $\begin{array}{l}0 \\
1+\end{array}$ & $\begin{array}{l}2591 \\
300\end{array}$ & $\begin{array}{l}89.6 \\
10.4\end{array}$ & 15 & $\begin{array}{l}2075 \\
223\end{array}$ & $\begin{array}{l}90.3 \\
9.7\end{array}$ & 11 \\
\hline Region & $\begin{array}{l}\text { North } \\
\text { Midlands } \\
\text { South } \\
\text { London } \\
\text { Wales } \\
\text { Scotland }\end{array}$ & $\begin{array}{l}474 \\
794 \\
957 \\
285 \\
132 \\
264\end{array}$ & $\begin{array}{l}16.3 \\
27.3 \\
32.9 \\
9.8 \\
4.5 \\
9.1\end{array}$ & 0 & $\begin{array}{l}377 \\
617 \\
785 \\
219 \\
107 \\
204\end{array}$ & $\begin{array}{l}16.3 \\
26.7 \\
34.0 \\
9.5 \\
4.6 \\
8.8\end{array}$ & 0 \\
\hline IMD Quintile & $\begin{array}{l}1 \text { (Most deprived) } \\
2 \\
3 \\
4 \\
5 \text { (Least deprived) }\end{array}$ & $\begin{array}{l}576 \\
545 \\
536 \\
638 \\
611\end{array}$ & $\begin{array}{l}19.8 \\
18.8 \\
18.4 \\
22.0 \\
21.0\end{array}$ & 0 & $\begin{array}{l}418 \\
405 \\
448 \\
528 \\
510\end{array}$ & $\begin{array}{l}18.1 \\
17.5 \\
19.4 \\
22.9 \\
22.1\end{array}$ & 0 \\
\hline Urban Rural & $\begin{array}{l}\text { Urban } \\
\text { Rural }\end{array}$ & $\begin{array}{l}2241 \\
665\end{array}$ & $\begin{array}{l}77.1 \\
22.9\end{array}$ & 0 & $\begin{array}{l}1750 \\
559\end{array}$ & $\begin{array}{l}75.8 \\
24.2\end{array}$ & 0 \\
\hline Long Term Condition & $\begin{array}{l}\text { No long term health condition } \\
\text { or disability } \\
\text { Non-limiting health condition } \\
\text { or disability } \\
\text { Limiting health condition or } \\
\text { disability }\end{array}$ & $\begin{array}{l}1766 \\
586 \\
541\end{array}$ & $\begin{array}{l}61.0 \\
20.3 \\
18.7\end{array}$ & 13 & $\begin{array}{l}1376 \\
499 \\
427\end{array}$ & $\begin{array}{l}59.8 \\
21.7 \\
18.5\end{array}$ & 7 \\
\hline Education & $\begin{array}{l}\text { Degree or equivalent } \\
\text { A level or equivalent } \\
\text { GCSE or equivalent } \\
\text { No Qualification }\end{array}$ & $\begin{array}{l}763 \\
760 \\
750 \\
582\end{array}$ & $\begin{array}{l}26.7 \\
26.6 \\
26.3 \\
20.4\end{array}$ & 51 & $\begin{array}{l}640 \\
616 \\
590 \\
427\end{array}$ & $\begin{array}{l}28.2 \\
27.1 \\
26.0 \\
18.8\end{array}$ & 36 \\
\hline Live Alone & $\begin{array}{l}\text { Alone } \\
\text { Not alone }\end{array}$ & $\begin{array}{l}913 \\
1993\end{array}$ & $\begin{array}{l}31.4 \\
68.6\end{array}$ & 0 & $\begin{array}{l}702 \\
1607\end{array}$ & $\begin{array}{l}30.4 \\
69.6\end{array}$ & 0 \\
\hline $\begin{array}{l}\text { Visited GP in the last } \\
12 \text { months }\end{array}$ & $\begin{array}{l}\text { In last } 12 \text { months } \\
\text { More than } 12 \text { Months/never }\end{array}$ & $\begin{array}{l}2386 \\
519\end{array}$ & $\begin{array}{l}82.1 \\
17.9\end{array}$ & 1 & $\begin{array}{l}1924 \\
385\end{array}$ & $\begin{array}{l}83.3 \\
16.7\end{array}$ & 0 \\
\hline Household income & $\begin{array}{l}\text { Less than } £ 1200 \text { p.m. } \\
£ 1200-2200 \text { p.m. } \\
£ 2201-3700 \text { p.m. } \\
£ 3701 \text { or more p.m. } \\
\text { Refused information }\end{array}$ & $\begin{array}{l}568 \\
577 \\
506 \\
528 \\
439\end{array}$ & $\begin{array}{l}21.7 \\
22.0 \\
19.3 \\
20.2 \\
16.8\end{array}$ & 288 & $\begin{array}{l}462 \\
470 \\
433 \\
456 \\
286\end{array}$ & $\begin{array}{l}21.9 \\
22.3 \\
20.6 \\
21.6 \\
13.6\end{array}$ & 202 \\
\hline Ethnicity & $\begin{array}{l}\text { White } \\
\text { BAME }\end{array}$ & $\begin{array}{l}2572 \\
334\end{array}$ & $\begin{array}{l}88.5 \\
11.5\end{array}$ & 0 & $\begin{array}{l}2098 \\
211\end{array}$ & $\begin{array}{l}90.9 \\
9.1\end{array}$ & 0 \\
\hline
\end{tabular}




\section{Abbreviations}

$\mathrm{HLQ}^{\mathrm{TM}}$ : Health literacy questionnaire ${ }^{\mathrm{TM}}$; BAME: Black Asian Minority Ethnic; IMD: Index of Multiple Deprivation; GCSE: General Certificate of Secondary Education; Cl: Confidence interval

\section{Acknowledgements}

The National Centre for Social Research undertook this survey as part of their British Social Attitudes survey. We thank the survey participants who completed the questionnaire.

\section{Authors' contributions}

AOC designed the study. EK contributed to the initial design of the study and supported the development of the survey instrument. RMS analysed and interpreted the data together with AOC. RMS and AOC drafted the manuscript. All authors participated in the interpretation of the results and contributed to the final writing of the paper. All authors read and approved the final manuscript.

\section{Funding}

This project was funded by the NIHR Health Services and Delivery Research (15/ 136/12). The views expressed are those of the authors and not necessarily those of the NHS, the NIHR or the Department of Health and Social Care.

Availability of data and materials

NatCen make the data from the British Social Attitudes survey available using their own data sharing processes.

\section{Ethics approval and consent to participate}

The NatCen Research Ethics Committee (REC) approved the British Social Attitudes survey (reference number P12598).

\section{Consent for publication}

Not applicable.

\section{Competing interests}

The authors declare that they have no competing interests.

Received: 6 December 2019 Accepted: 19 October 2020

Published online: 30 November 2020

\section{References}

1. World Health Organization (WHO). Health Promotion Glossary. 1998. https:// www.who.int/healthpromotion/about/HPR Glossary 1998.pdf. Accessed 23 Jul 2019..

2. Nutbeam D. Defining and measuring health literacy: what can we learn from literacy studies? Int J Public Health. 2009;54:303-5. https://doi.org/10. 1007/s00038-009-0050-x.

3. Bostock S, Steptoe A. Association between low functional health literacy and mortality in older adults: longitudinal cohort study. BMJ. 2012;344.

4. Haun JN, Patel NR, French DD, Campbell RR, Bradham DD, Lapcevic WA Association between health literacy and medical care costs in an integrated healthcare system: a regional population based study. BMC Health Serv Res. 2015;15.

5. Miller TA. Health literacy and adherence to medical treatment in chronic and acute illness: a meta-analysis. Patient Educ Couns. 2016;99:1079-86.

6. Weiss BD, Mays MZ, Martz W, Castro KM, DeWalt DA, Pignone MP, et al. Quick assessment of literacy in primary care: the newest vital sign. Ann Fam Med. 2005;3:514-22.

7. Parker RM, Baker DW, Willia MV, Nurss JR. The test of functional health literacy in adults: a new instrument for measuring patients' literacy skills. J Gen Intern Med. 1995:10:537-41.

8. Osborne RH, Batterham RW, Elsworth GR, Hawkins M, Buchbinder R. The grounded psychometric development and initial validation of the health literacy questionnaire (HLQ). BMC Public Health. 2013;13:658. https://doi.org/ 10.1186/1471-2458-13-658

9. Jordan JE, Buchbinder R, Briggs AM, Elsworth GR, Busija L, Batterham R, et al The health literacy management scale (HeLMS): a measure of an individual's capacity to seek, understand and use health information within the healthcare setting. Patient Educ Couns. 2013;91:228-35.
10. Steckelberg A, Hülfenhaus C, Kasper J, Rost J, Mühlhauser I. How to measure critical health competences: development and validation of the critical health competence test (CHC test). Adv Heal Sci Educ. 2009;14:11-22.

11. Kutner, Greenberg, Jin, Paulsen. The health literacy of America's adults: results from the 2003 National Assessment of Adult Literacy. 2003. https:// nces.ed.gov/pubs2006/2006483.pdf. Accessed 23 July 2019.

12. Sørensen K, Van Den Broucke S, Pelikan JM, Fullam J, Doyle G, Slonska Z, et al. Measuring health literacy in populations: illuminating the design and development process of the European health literacy survey questionnaire (HLS-EU-Q). BMC Public Health. 2013;13.

13. Friis $\mathrm{K}$, Lasgaard $\mathrm{M}$, Osborne $\mathrm{RH}$, Maindal HT. Gaps in understanding health and engagement with healthcare providers across common long-term conditions: a population survey of health literacy in 29473 Danish citizens. BMJ Open. 2016;6:e009627. https://doi.org/10.1136/BMJOPEN-2015-009627.

14. van der Gaag M, van der Heide I, Spreeuwenberg PMM, Brabers AEM, JJDJM R. Health literacy and primary health care use of ethnic minorities in the Netherlands. BMC Health Serv Res. 2017;17:350. https://doi.org/10.1186/ s12913-017-2276-2.

15. Bo A, Friis K, Osborne RH, Maindal HT. National indicators of health literacy: ability to understand health information and to engage actively with healthcare providers - a population-based survey among Danish adults. BMC Public Health. 2014;14:1095. https://doi.org/10.1186/1471-2458-14-1095.

16. Beauchamp A, Buchbinder R, Dodson S, Batterham RW, Elsworth GR, McPhee $C$, et al. Distribution of health literacy strengths and weaknesses across socio-demographic groups: a cross-sectional survey using the health literacy questionnaire (HLQ). BMC Public Health. 2015;15:678. https://doi.org/ 10.1186/s12889-015-2056-z.

17. Protheroe J, Whittle R, Bartlam B, Estacio EV, Clark L, Kurth J. Health literacy, associated lifestyle and demographic factors in adult population of an English city: a cross-sectional survey. Health Expect. 2017;20:112. https://doi. org/10.1111/HEX.12440.

18. Curtice J, Clery E, Perry J, Phillips M, Rahim N. British social attitudes: the 36th report. London: The National Centre for Social Research; 2019

19. 4364.0.55.014 - National Health Survey: Health Literacy, 2018. https://www abs.gov.au/AUSSTATS/abs@.nsf/Lookup/4364.0.55.014Main+Features1201 8?OpenDocument. Accessed 7 May 2020.

20. Nolte S, Osborne RH, Dwinger S, Elsworth GR, Conrad ML, Rose M, et al. German translation, cultural adaptation, and validation of the health literacy questionnaire (HLQ); 2017. https://doi.org/10.1371/journal.pone.0172340.

21. Maindal HT, Kayser L, Norgaard O, Bo A, Elsworth GR, Osborne RH. Cultural adaptation and validation of the health literacy questionnaire (HLQ): robust nine-dimension Danish language confirmatory factor model. Springerplus. 2016;5:1-16. https://doi.org/10.1186/s40064-016-2887-9.

\section{Publisher's Note}

Springer Nature remains neutral with regard to jurisdictional claims in published maps and institutional affiliations.

Ready to submit your research? Choose BMC and benefit from:

- fast, convenient online submission

- thorough peer review by experienced researchers in your field

- rapid publication on acceptance

- support for research data, including large and complex data types

- gold Open Access which fosters wider collaboration and increased citations

- maximum visibility for your research: over $100 \mathrm{M}$ website views per year

At $\mathrm{BMC}$, research is always in progress.

Learn more biomedcentral.com/submissions 